\title{
Cytotoxic and mutagenic potential of juglone: a comparison of free and nano-encapsulated form
}

\author{
Semiha Erisen ${ }^{1}$, Tülin Arasoğlu1, Banu Mansuroglu¹, İsmail Kocacaliskan¹, and Serap Derman² \\ ${ }^{1}$ Yildiz Technical University, Faculty of Science and Letters Molecular Biology and Genetics Department, Esenler- \\ Istanbul, Turkey \\ 2 Yildiz Technical University, Faculty of Chemical and Metallurgical Engineering, Department of Bioengineering, \\ Istanbul, Turkey
}

[Received in October 2019; Similarity Check in October 2019; Accepted in February 2020]

\begin{abstract}
Despite its evidenced beneficial herbicidal, antibacterial, antiviral, antifungal, and antioxidant effects, the application of juglone (5-hydroxy-1,4,-naphthoquinone) is limited due to its low water solubility and allelopathic and toxic effects. In recent years, research has aimed to overcome these limitations by increasing its solubility and controlling its release through nanoparticular systems. This is the first study to have synthesised and characterised juglone-loaded polymeric nanoparticles and compared them with free juglone for cytotoxicity in mouse (L929 fibroblasts) and alfalfa cells and for mutagenic potential in Salmonella typhimurium TA98/100. Mouse and plant cells treated with free and nano-encapsulated juglone showed a decrease in cell viability in a dose and time-dependent manner, but this effect was significantly lower with the nanoencapsulated form at lower doses. In the TA98 strain with S9, nano-encapsulated juglone did not exhibit mutagenic effects, unlike the free form. Since all results show that juglone encapsulation with polymeric nanoparticles reduced the toxic and mutagenic effects, it has a promising potential to be applied in medicine, food safety, and agriculture.
\end{abstract}

KEY WORDS: alfalfa; L929 fibroblasts; nanoparticle; PLGA; S. typhimurium

Walnut preparations are used in traditional medicine for the treatment of many health problems such as fungal, bacterial, viral, and helminthic infections, hypotension, hypoglycaemia, and even cancer (1). Walnut has the highest concentrations of an allelochemical molecule which is an amber pigment largely responsible for its biological activity (Figure 1) (2). Juglone is found in the root, leaves, bark, and nuts of several walnut species of the Juglandaceae family, including Juglans nigra, Juglans regia, Juglans cinerea, and Carya illinoinensis (3). Even though it is poorly soluble in water, juglone will adversely affect plants growing around the tree $(2,4)$. In terms of its toxicity mechanisms, a number of studies have established that it causes cell death, disrupts the cell cycle, modifies DNA (especially in rapidly dividing cells), inhibits mRNA synthesis, alkylates basic protein thiol or amine groups, and reduces tumour suppressor levels $(2,5-7)$.

Nowadays, new antibiotics are needed to address increasing antimicrobial resistance, but their development and approval cannot keep up the pace with this issue (8). It is therefore essential to develop new antibacterials with different bacterial killing mechanisms than those of conventional antibiotics. Considering its high antimicrobial effect against infections, juglone bears a promise in this

Corresponding author: Tülin Arasoğlu, Yildiz Technical University, Faculty of Science and Letters, Molecular Biology and Genetics Department, 34220, Esenler-Istanbul/Turkey, E-mail: ozbektulin@gmail.com respect. It has already been evidenced for herbicidal (9), antibacterial (10-13), antiviral (14), antifungal $(15,16)$, antioxidant (13), antiparasitic (17), and anticancer (18-20) properties. However, its hydrophobic structure and high toxicity limit its application in biological systems $(2,4)$.

A promising strategy to overcome this limitation of juglone and many other materials comes with nanosized drug delivery systems, which have attracted considerable interest in recent years $(21,22)$. Nanoparticulate systems provide greater biocompatibility and bioavailability and lower the doses of active substances, still achieving the desired effect through controlled release $(23,24)$. This is particularly true for polymeric nanoparticles such as the poly (D,L-lactic-co-glycolic acid) (PLGA) polymer, as it increases biocompatibility and therapeutic index of active ingredients (Figure 1) (22). Biodegradation of PLGA does not lead to toxicity. Lactic acid from hydrolysis products enters the tricarboxylic acid cycle and is excreted as carbon dioxide and water. Glycolic acid is likewise metabolised to carbon dioxide and water or directly excreted from the kidneys (25).

The aim of this study was therefore to compare cytotoxic and mutagenic properties of juglone-loaded polymeric nanoparticles (JNPs) with those of free juglone. For this purpose, we encapsulated juglone in PLGA nanoparticles, and characterised their physicochemical and release profile. Then, for the first time in literature, we compared the cytotoxic activity of JNPs with juglone in plant cell (alfalfa) 


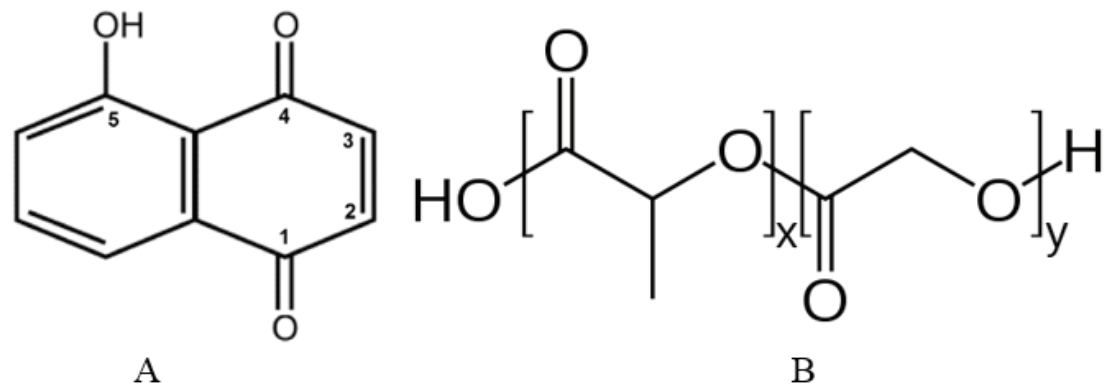

Figure 1 Chemical structure of juglone (A) and poly (lactic-co-glycolic acid) (B)

and mouse cell culture (L929 fibroblast cells). Additionally, we investigated their mutagenic potential in Salmonella typhimurium strains TA98 and TA100 in culture media with or without the $\mathrm{S} 9$ metabolic activation system.

\section{MATERIALS AND METHODS}

\section{Materials}

Juglone (Mw: 174.15 g/mol, CAS Number: 481-39-0), polyvinyl alcohol (PVA, Mw 31-50 kDa, 87-89 \% hydrolyzed, CAS Number: 9002-89-5), PLGA (50:50 lactide:glicolide; inherent viscosity $0.45-0.60 \mathrm{dL} / \mathrm{g}, \mathrm{Mw}$ 38-54 kDa, CAS Number: 26780-50-7), and dichloromethane (DCM, CAS Number: 75-09-2) were purchased from Sigma-Aldrich (St. Louis, MO, USA).

Plant suspension cultures were established from alfalfa (Medicago sativa cv Verco) seeds kindly provided by Dr Satı Uzun (University of Erciyes, Turkey). 2,4-dichlorophenoxyacetic acid, kinetin, sucrose, and agar used for preparing the Murashige and Skoog (MS) medium were purchased from Sigma-Aldrich.

The mouse fibroblast cell line L929 was obtained from the American Type Culture Collection (ATCC, Manassas, VA, USA). Dulbecco's modified Eagle's medium (DMEM) / Ham's Nutrient Mixture F-12 medium, foetal bovine serum (FBS), penicillin, and L-glutamine used in the preparation of fibroblast cell cultures were purchased from SigmaAldrich. The Ames Microplate Format Mutagenicity Assay ${ }^{\text {TM }}$ 98/100 kit and strains were provided from AnariaXenometrix (Mason, OH, USA). All the chemicals and solvents used for mutagenicity study were of analytical grade. Ultra-pure water was obtained from the Millipore MilliQ Gradient system (Merck Millipore, Burlington, MA, USA)

\section{Nanoparticle synthesis and characterisation}

Juglone-loaded nanoparticles (JNPs) were synthesised using the single-emulsion solvent evaporation method described in our previous study (16) with minor modifications. $20 \mathrm{mg}$ of juglone and $100 \mathrm{mg}$ of PLGA were first dissolved in $3.5 \mathrm{~mL} \mathrm{DCM}$ and stirred to ensure that all materials were dissolved. The obtained organic phase was added dropwise to $8 \mathrm{~mL}$ of aqueous PVA solution ( $3 \% \mathrm{w} / \mathrm{v}$ ) over an ice bath, and the mixture was sonicated with a microtip probe sonicator (HD3100, Bandelin, Berlin, Germany, output power $100 \mathrm{~W}$ ) at $80 \%$ power for 2 min. The obtained oil-in-water $(\mathrm{o} / \mathrm{w})$ emulsion was then diluted in $35 \mathrm{~mL}$ of PVA solution $(0.1 \% \mathrm{w} / \mathrm{v})$ and mixed on a magnetic stirrer at room temperature overnight for the organic solvent to evaporate. The obtained nanoparticles were centrifuged at 10,000 $\mathrm{xg}$ for $40 \mathrm{~min}$ (Beckman Coulter, Allegra-X-30R) and washed three times with ultrapure water. After that, the suspensions were lyophilised and solid nanoparticles stored at $-80^{\circ} \mathrm{C}$ until use.

Encapsulation efficiency and drug loading were determined by indirect quantification using UV-vis spectroscopy (UV 1800, Shimadzu, Tokyo, Japan). UV absorbance of the supernatant was analysed at $424 \mathrm{~nm}$ in triplicate. Juglone concentration was calculated using a previously constructed standard calibration curve (26). Encapsulation efficiency (EE) and drug loading (DL) of juglone were calculated as follows:

$$
\begin{aligned}
& \mathrm{EE} \%=\frac{\text { Encapsulated juglone in NPs }(\mathrm{mg})}{\text { Encapsulated juglone amount }(\mathrm{mg})} \\
& \mathrm{DL} \%=\frac{\text { Encapsulated juglone in } \mathrm{NPS}(\mathrm{mg})}{\text { Obtained nanoparticle amount }(\mathrm{mg})} \times 100
\end{aligned}
$$

The mean diameter, particle size distribution, zeta potential $(\zeta)$, and polydispersity index (PDI) of the nanoparticles were investigated by photon correlation spectroscopy using a Zetasizer Nano ZS (Malvern, UK) instrument (27). Nanoparticles were also inspected for shape and surface morphology with scanning electron microscopy (SEM, A JSM-7001FA, Jeol, Japan) as previously described in our studies (10), with an acceleration voltage of 10-30 kV. Successful encapsulation of juglone was evidenced with Fourier-transform infrared spectroscopy (FT-IR) using an IR-Prestige 21 FT-IR spectrophotometer (Shimadzu, Kyoto, Japan) in ATR mode. The FT-IR spectra ranging between 600 and $4000 \mathrm{~cm}^{-1}$ were obtained with resolution of $4 \mathrm{~cm}^{-1}(28)$.

Juglone release was established with a modified dissolution method in triplicate, in which $5 \mathrm{mg}$ of nanoparticles were suspended in $2 \mathrm{~mL}$ of phosphate buffer saline (PBS) and incubated $37^{\circ} \mathrm{C}$ in a shaking incubator $(150 \mathrm{rpm})$ at $\mathrm{pH}$ of 7.2 (16). The suspensions were 
centrifuged and the obtained precipitates, resuspended with $2 \mathrm{~mL}$ of fresh PBS, and supernatants analysed with UV-vis spectroscopy at $424 \mathrm{~nm}$. The amount of released juglone was calculated using a previously constructed calibration curve (26).

\section{Fibroblast cell cytotoxicity evaluation}

L929 fibroblast cell lines were grown at $37{ }^{\circ} \mathrm{C}$ in DMEM/Ham's Nutrient Mixture F-12 medium (1:1) supplemented with $10 \% \mathrm{FBS}, 100 \mu \mathrm{g} / \mathrm{mL}$ streptomycin, 100 units/ $\mathrm{mL}$ penicillin, and $0.2 \mathrm{mmol} / \mathrm{L}$ L-glutamine in an atmosphere of $95 \%$ air and $5 \% \mathrm{CO}_{2}$. The medium was changed every two days. The morphology of the cells was examined with an Olympus phase contrast microscope (Olympus CKX41, Tokyo, Japan) at 5x magnification.

The cytotoxic potential of juglone was quantified with the MTT assay (3-(4,5-dimethylthiazol-2-yl)-2,5diphenyltetrazolium bromide) (29) following the ISO 10993-5 procedure (30). Briefly, $5 \times 10^{3}$ fibroblast cells per well were seeded in 96 -well plates and incubated at $37^{\circ} \mathrm{C}$ for $24 \mathrm{~h}$ and then exposed to free and nano-encapsulated juglone in concentrations of 5, 27, 83, 160, 250, 500, and $1000 \mu \mathrm{mol} / \mathrm{L}$ suspended in DMEM/ Ham's Nutrient Mixture F-12 medium (1:1). Following 24- and 48-hour incubation, the supernatant from each well was replaced with fresh MTT reagent in the final concentration of $50 \mu \mathrm{g} / \mathrm{mL}$ of medium. The cells were then incubated at $37^{\circ} \mathrm{C}$ for $3 \mathrm{~h}$, and their viability determined by measuring absorbance at $570 \mathrm{~nm}$ in a universal microplate reader. Control growth was considered to be $100 \%$ viable. Metabolic activity was expressed as mean \pm SD. Cell viability (\%) was calculated as follows:

$$
\text { Cell viability }(\%)=\frac{O D \text { value of treated cells }}{O D \text { value of untreated cells }(\text { control) }} \times 100
$$

\section{Alfalfa cell cytotoxicity evaluation}

Leaf explants $(5-6 \mathrm{~cm})$ removed from in vitro aseptic seedling of alfalfa were cultured on MS medium supplemented with $3 \mathrm{mg} / \mathrm{L}$ 2,4-dichlorophenoxyacetic acid, $0.5 \mathrm{mg} / \mathrm{L}$ kinetin, $3 \%(\mathrm{w} / \mathrm{v})$ sucrose, and $0.8 \%(\mathrm{w} / \mathrm{v})$ agar for callusing. The $\mathrm{pH}$ of the medium was adjusted to 5.6 before autoclaving at $121^{\circ} \mathrm{C}$ for $20 \mathrm{~min}$. After six weeks, cell suspension cultures were initiated in $150 \mathrm{~mL}$ Erlenmeyer flasks with $1 \mathrm{~g}$ of friable callus in $50 \mathrm{~mL}$ of MS liquid medium containing plant growth regulator used for the callus phase. The cultures were kept in a dark growth chamber at $24 \pm 2{ }^{\circ} \mathrm{C}$ under continuous agitation of $110 \mathrm{rpm}$ in an orbital shaker. After 21 days, $30 \mathrm{~mL}$ of fresh medium was added to $10 \mathrm{~mL}$ of decanted suspension culture, and the suspensions were subcultured every 10 days by transferring 10-30 $\mathrm{mL}$ of fresh medium. Cell density was determined as $\sim 1.5 \times 10^{5}$ cells $/ \mathrm{mL}$ using the Thoma cell counting chamber. These cultures were used as stock.

Alfalfa cells were exposed to the same free and nanoencapsulated juglone concentrations as the mouse cells. 100 $\mu \mathrm{L}$ free or nano-encapsulated juglone solutions were added to $4 \mathrm{~mL}$ of 5-6 day old alfalfa suspension cultures under continuous agitation at $110 \mathrm{rpm}$ in an orbital shaker. After 24 and $48 \mathrm{~h}$ of incubation, cell suspensions $(1 \mathrm{~mL})$ were transferred to tubes and centrifuged at $445 \mathrm{xg}$ for $5 \mathrm{~min}$ to collect the cells. Cell viability was determined with the MTT assay with minor modifications (31). $100 \mu \mathrm{L}$ of a $5 \mathrm{mg} / \mathrm{mL}$ MTT solution was added to each tube and incubated in dark on a shaker at $24{ }^{\circ} \mathrm{C}$ for $2 \mathrm{~h}$. The pellet was removed by centrifugation at $1000 \mathrm{xg}$ for $5 \mathrm{~min}$ and resuspended with $200 \mu \mathrm{L}$ of DMSO for $10 \mathrm{~min}$. The supernatant was placed on microplate and analysed at $570 \mathrm{~nm}$ in a universal microplate reader. Cell viability (\%) was calculated as follows:

$$
\text { Cell viability }(\%)=\frac{O D \text { value of treated cells }}{\text { OD value of untreated cells (control) }} \times 100 \quad \text { [4] }
$$

\section{Bacterial cell mutagenicity and cytotoxicity evaluation}

To determine juglone mutagenicity we chose the Ames MPF assay as a method that shows reverse mutagenicity in Salmonella typhimurium strains TA98 and TA100. These strains cannot grow in histidine-free media, since they have lost the ability to produce histidine due to point mutations (either frame-shift for TA98 or base-pair for TA100) in the histidine (His) operon. However, a new mutation in this operon (such as the one caused by juglone) reverts His auxotroph into a prototroph and reverts the initial mutation so that the strains can now grow in histidine-free media. Frozen stock cultures of $S$. typhimurium TA98 and TA100 strains in histidine-free medium were thawed at room temperature and pipetted to be completely homogenised. They were prepared by incubating in tubes containing $10 \mathrm{~mL}$ growth medium and $10 \mu \mathrm{L}$ ampicillin $(50 \mathrm{mg} / \mathrm{mL})$ at $37{ }^{\circ} \mathrm{C}$ and shaking at $200 \mathrm{rpm}$ for $16-18 \mathrm{~h}$ overnight. When the cultures reached spectrophotometric $\mathrm{OD}_{600} \geq 2.0$, they were ready for mutagenicity testing.

The mutagenic activity of free and nano-encapsulated juglone was determined with the Ames MPFTM 98/100 bacterial reverse mutation assay (Anaria-Xenometrix, Mason, OH, USA) with or without the metabolic activation of the rat liver S9 microsomal fraction. The study was carried out in accordance with the kit protocol (32). 2-nitrofluorene (2NF; $2 \mu \mathrm{g} / \mathrm{mL}$ ), 4-nitroquinalone- $N$-oxide (4NQO; $0.1 \mu \mathrm{g} / \mathrm{mL}$ ), and 2-aminoanthracene (2-AA; $2.5 \mu \mathrm{g}$ / $\mathrm{mL}$ for TA100, $1.0 \mu \mathrm{g} / \mathrm{mL}$ for TA98) were used as positive control (mutagens). Water (solvent) was used as negative control. The S9 metabolic activation system was prepared as a $30 \%$ mix of S9 fraction and cofactors (32-34). Free and nano-encapsulated juglone stock concentrations were set to contain $5.7 \mathrm{mmol} / \mathrm{L}$ juglone. The final concentration of juglone applied to all wells ranged between 0.31 and $10 \mu \mathrm{mol} / \mathrm{L}$. Bacterial cultures in a 24 -well plate were exposed to $10 \mu \mathrm{L}$ of free or nano-encapsulated juglone stock solution for $90 \mathrm{~min}\left(37^{\circ} \mathrm{C}, 250 \mathrm{rpm}\right)$. The liquid exposure medium contained trace amounts of required histidine. In the presence of $\mathrm{S} 9$, the volume of the exposure medium was reduced as indicated in the kit to produce a $240 \mu \mathrm{L}$ mix 
of S9 and exposure medium containing bacterial culture. This mix was added to the wells containing juglone solutions, resulting in a total volume of $250 \mu \mathrm{L}$. At the end of exposure, each well of the 24 -well plates received $2.6 \mathrm{~mL}$ of histidine-free indicator medium. $50 \mu \mathrm{L}$ of the culture in each well was taken and distributed to a 384-well plate. After $48 \mathrm{~h}$ of incubation at $37^{\circ} \mathrm{C}$, the metabolism of prototroph cells that succeeded to reproduce in histidinefree medium lowers the $\mathrm{pH}$ of the substrate, causing a change in colour from purple (bromosresol) to yellow as a result of the catabolic activity of the revertant bacteria. This colour is interpreted as a mutagenic effect, and each well is scored for either yellow (mutagenic effect or positive control) or purple (no-mutagenic effect or solvent control) $(32,34,35)$.

Juglone cytotoxicity to the $S$. typhimurium TA98 and 100 strains was investigated as described in the "pre-screen determination of dose range" section of the kit protocol (32). Only free juglone was evaluated, because we did not expect any problem with the solubility of the PLGA nanoparticle system, from which juglone is slowly released. The kit protocol recommends the use of 25 times higher stock sample concentrations than the highest concentration to be used in the mutagenicity study. However, as juglone water solubility is very low, we adjusted its concentration range from 2.5 to $80 \mu \mathrm{mol} / \mathrm{L}$. Briefly, bacterial overnight cultures were incubated in exposure medium at $37^{\circ} \mathrm{C}$ for 90 min and measured spectrophotometrically at $\mathrm{OD}_{600}$. The results were evaluated according to turbidity and sediment. Being an indication of bacterial lysis, pure image is an indicator of a cytotoxic dose. The well containing a lower dose should be more blurred and have no sediment at the bottom. The highest concentration to be applied in the Ames assay was therefore the lowest sample concentration with the highest solubility and no cytotoxicity.

\section{Statistical analysis}

Cytotoxicity results [means of four (mammalian cells) and three (plant cells) independent treatments repeated for all groups, starting with the cell growth step] were analysed with a GraphPad Prism6 software (San Diego, CA, USA). The differences between JNPs and free juglone within each dose were determined using the $t$-test. P values $<0.05$ were considered significant. $\mathrm{IC}_{50}$ values were calculated using Prism6.

The criteria for the evaluation of mutagenicity results (means \pm standard deviations of the number of revertant wells) were the number of positive wells and dose dependency $(32,34,36)$. The data were evaluated with the cumulative binomial distribution test according to the manufacturer's instructions. The increase of revertants relative to the solvent control was determined by dividing the mean number of positive wells (yellow well) at each dose with solvent control baseline, which is obtained by adding one standard deviation to the mean number of positive wells of the solvent control. A twofold or higher increase over baseline was considered a mutagenic effect. The dose-response relationship and the differences were considered significant when the binomial value was $\geq 99 \%$ (21).

\section{RESULTS AND DISCUSSION}

Table 1 shows the physicochemical properties of JNPs. In terms of encapsulation efficiency and drug loading activities our results are compatible with similar reports in the literature (37-39).

JNPs had a narrow size distribution (Figure 2A), and were quite spherical, smooth, and homogeneous in size (Figure 2B SEM image).

Figure 2C compares the FT-IR absorbance spectra of free juglone, JNPs, and juglone-free PLGA nanoparticles. Juglone exhibited the main characteristic triple peaks at $1593 \mathrm{~cm}^{-1}\left(\mathrm{C}_{2}=\mathrm{C}_{3}\right), 1635 \mathrm{~cm}^{-1}\left(\mathrm{C}_{4}=\mathrm{O}\right)$, and $1662 \mathrm{~cm}^{-1}$ $\left(\mathrm{C}_{1}=\mathrm{O}\right)$, while the peak at $1288 \mathrm{~cm}^{-1}$ corresponds to the $\mathrm{C}_{5}-\mathrm{O}$ group. Unlike juglone, both PLGA and JNPs have a carbonyl group absorbance band at $1751 \mathrm{~cm}^{-1}$. A comparison of all three spectra clearly shows a similarity between JNPs and PLGA, and the absence of juglone's specific peak in the JNPs spectrum indicates that juglone was successfully coated with the PLGA nanoparticles.

Juglone cumulative release from the nanoparticles in phosphate buffer saline at $\mathrm{pH} 7.4$ shows a triphasic pattern of up to 30 days (Figure 2D). It starts with $28.62 \pm 2.3 \%$ at the end of the first hour, then soars to $56.53 \pm 2.5 \%$ at the end of hour 24 , and peaks to $88.86 \pm 2.8 \%$ at the end of day 9. After that, it slows down to finally reach $92.72 \pm 4.1 \%$ at the end of day 30 .

\section{Juglone/JNP effect on fibroblast cell viability}

Figure 3 shows the inhibitory effects of juglone and JNPs on L929 fibroblast cell viability (measured with the MTT assay). In the first $24 \mathrm{~h}$, juglone and JNP had a similar cytotoxic effect, with half-maximal inhibitory concentrations $\left(\mathrm{IC}_{50}\right)$ of 290 and $330 \mu \mathrm{mol} / \mathrm{L}$, respectively (Figure 3A). After $48 \mathrm{~h}$, free juglone toxicity became far more prominent, with $\mathrm{IC}_{50}$ of $60 \mu \mathrm{mol} / \mathrm{L}$, as opposed to $270 \mu \mathrm{mol} / \mathrm{L}$ for JNPs (Figure 3B). Cell viability drastically dropped at juglone concentrations of $83 \mu \mathrm{mol} / \mathrm{L}(\mathrm{p}=0.038), 160 \mu \mathrm{mol} / \mathrm{L}$ $(\mathrm{p}=0.013)$, and $250 \mu \mathrm{mol} / \mathrm{L}(\mathrm{p}=0.034)$ compared to JNPs. In a study by Ramirez et al. (40), high cytotoxic activity of synthetic juglone and its derivatives on L929 fibroblast cells began at the lowest concentration $(5.3 \mu \mathrm{mol} / \mathrm{L})$ applied. Cytotoxic activity this high might be advantageous for cancer cell lines, but is unwelcome in other therapeutic applications. Significantly lower cytotoxic effect of JNPs is therefore an advantage here, most likely thanks to low and sustained release from the nanosystem. This is in line with reports that biodegradable nanoparticles used as drug 
Table 1 Physicochemical properties of juglone loaded PLGA nanoparticles

\begin{tabular}{ccccc}
\hline $\begin{array}{c}\text { Encapsulating efficiency } \\
(\%)\end{array}$ & $\begin{array}{c}\text { Drug loading } \\
(\mathbf{\%})\end{array}$ & $\begin{array}{c}\text { Particle size } \\
(\mathbf{n m})\end{array}$ & $\begin{array}{c}\text { Zeta potential } \\
(\mathbf{m V})\end{array}$ & Polydispersity index \\
\hline $29.95 \pm 2.8$ & $15.42 \pm 2.1$ & $213.33 \pm 5.2$ & $-14.58 \pm 2.8$ & $0.115 \pm 0.03$ \\
\hline
\end{tabular}
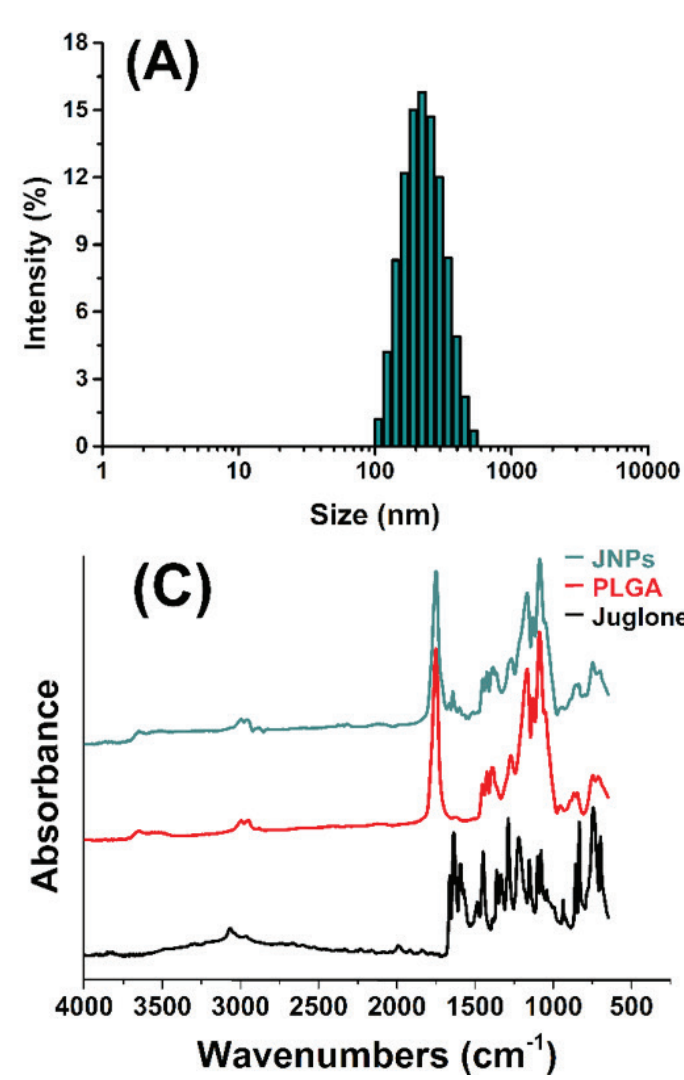

Figure 2 Particle size distribution (A), scanning electron microscopy image (B), FT-IR spectra (C), and release pattern (D) of nanoparticles

carriers protect substances from degradation and reduce their toxicity or side effects (41).

\section{Juglone/JNP effect on alfalfa cell viability}

Similar to the fibroblast cells, the cytotoxicity of either free or nano-encapsulated juglone in alfalfa cells was dosedependent and was not significant at doses lower than 27 and $83 \mu \mathrm{mol} / \mathrm{L}$, respectively. Similar was reported by other studies for alfalfa and other plants (42-47).

Free and nano-encapsulated juglone did not significantly differ in their effect on cell viability in the first $24 \mathrm{~h}$ either (Figure 4A), with respective $\mathrm{IC}_{50}$ of 316 and $382 \mu \mathrm{mol} / \mathrm{L}$. After $48 \mathrm{~h}$, however, free juglone doses of 5 and $27 \mu \mathrm{mol} / \mathrm{L}$ had a significantly higher cytotoxic effect (Figure 4B). The respective $\mathrm{IC}_{50}$ dropped to $2 \mu \mathrm{mol} / \mathrm{L}$ for juglone and $70 \mu \mathrm{mol} / \mathrm{L}$ for JNPs.

\section{Ames test findings}

According to the spectrophotometric measurements and turbidimetric observation $\left(\mathrm{OD}_{600}\right)$, the juglone dose of 10 $\mu \mathrm{mol} / \mathrm{L}$ was selected as the highest non-cytotoxic concentration applied in the Ames test. Figures 5 and 6 show the results for S. typhimurium TA98 and 100 strains
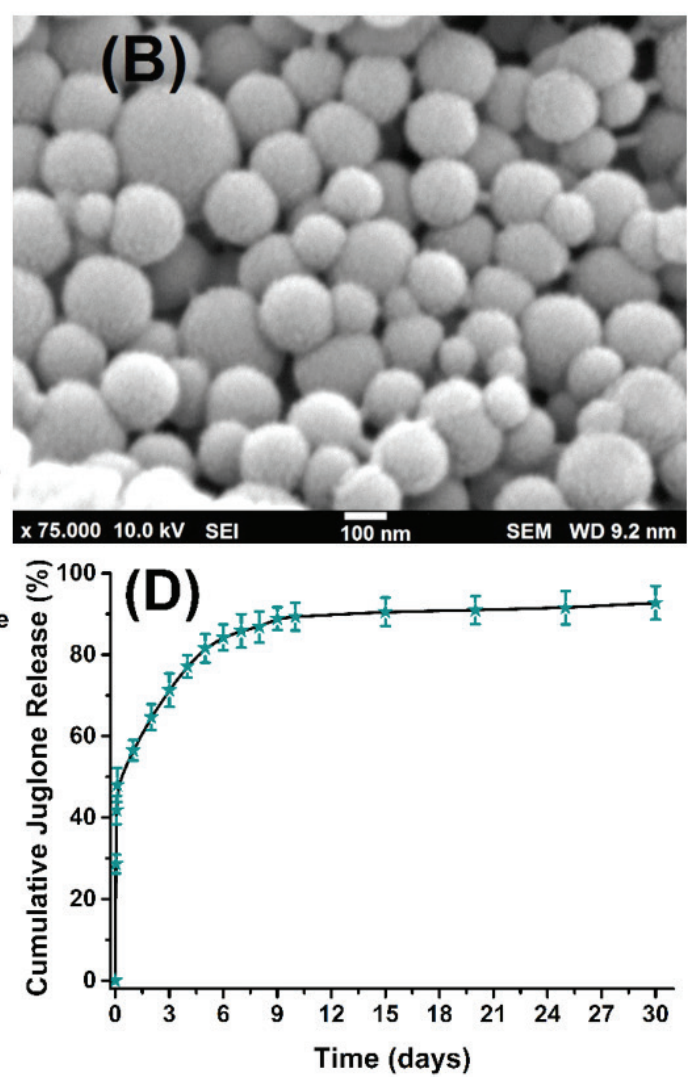

in the absence (-S9) and presence (+S9) of metabolic activation. Juglone showed mutagenic activity at 2.5 and $1.25 \mu \mathrm{mol} / \mathrm{L}$ on TA98 strain with $\mathrm{S} 9$ metabolic activation system but not on TA100 with or without S9. Juglone also significantly increased the number of revertant wells at the concentration of $0.62 \mu \mathrm{mol} / \mathrm{L}$ in the TA98 strain without the $\mathrm{S} 9$ medium (B value $\geq 0.99$ ), but this increase was not considered mutagenic, because it still was not twice the baseline.

Our results indicate that juglone causes frameshift mutations which may be related to hydroxyl substitution. In the mutagenicity study carried out on natural quinones by Tikkaen et al. (48) hydrocarbons with simple hydroxyl and/or methyl substituents were extremely important for the mutagenic effect, and while juglone showed a mutagenic effect on the TA2637 strain with S9 metabolic activation, the effect was extremely weak in the TA98 strain. These results are consistent with our study. In another study (49), the mutagenic effect of juglone on S. typhimurium TA98 in the presence of the $\mathrm{S} 9$ metabolic activation system was dose-independent, and, according to the authors, related to the hydroxyl group at position 5. Besides, juglone is biotransformed by liver metabolism and may affect several 

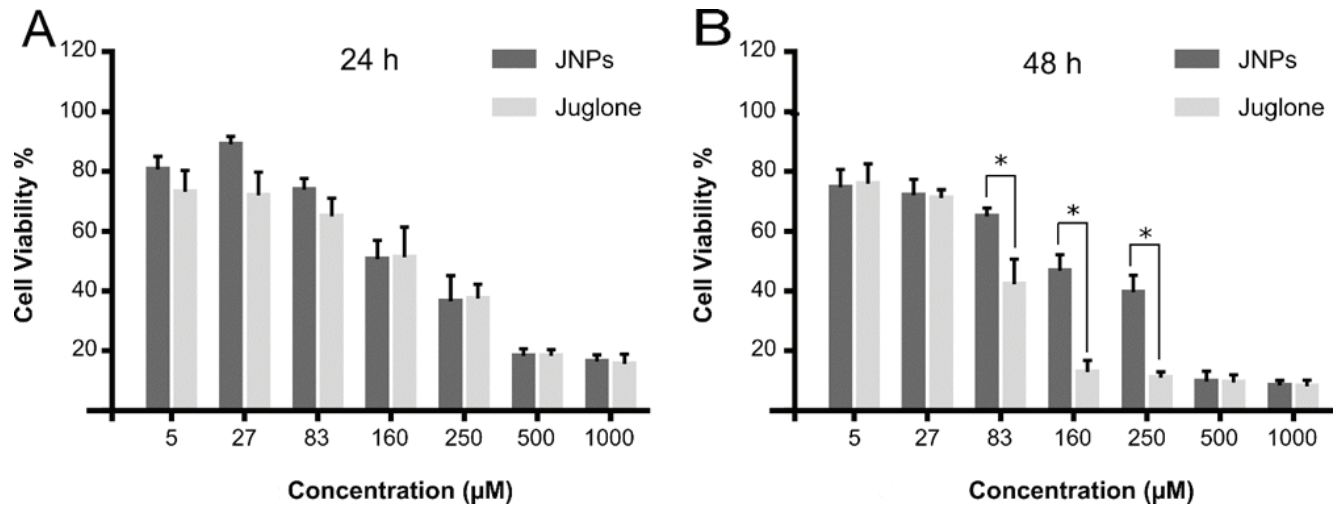

Figure 3 Viability of L929 fibroblasts treated with free and PLGA nanoparticle-coated juglone (JNP) after 24 h (A) and 48 h (B); Cell viability was measured with the MTT assay. Values are expressed as means of quadruple samples with standard error. *statistically significant differences between juglone and JNP $(\mathrm{p}<0.05)$
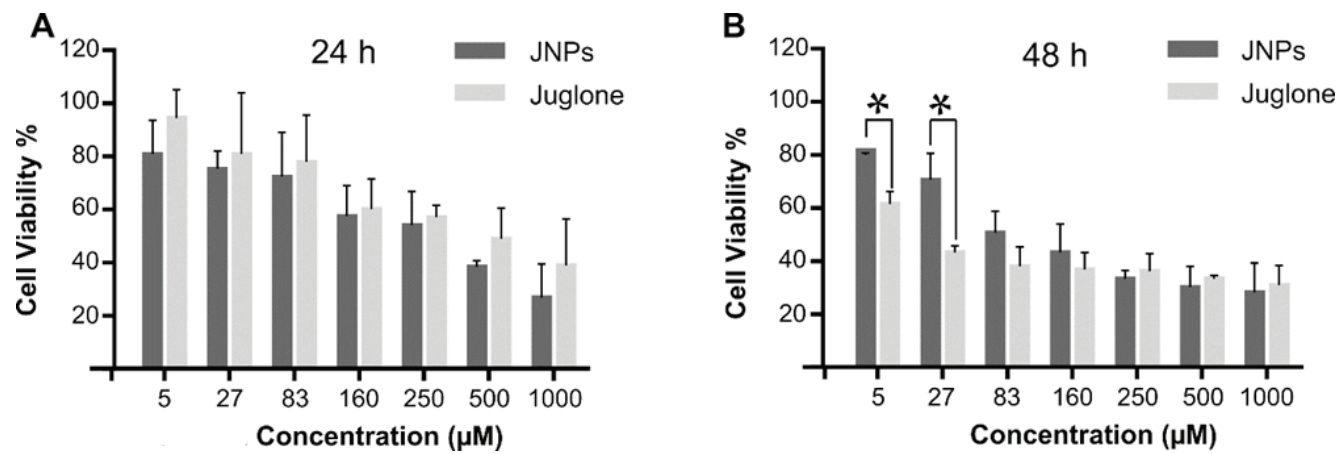

Figure 4 Viability of alfalfa cells treated with free and PLGA nanoparticle-coated juglone (JNP) after $24 \mathrm{~h} \mathrm{(A)} \mathrm{and} 48$ h (B); Cell viability was measured with the MTT assay. Values are expressed as means of triple samples with standard error. *statistically significant differences between juglone and JNP $(\mathrm{p}<0.05)$
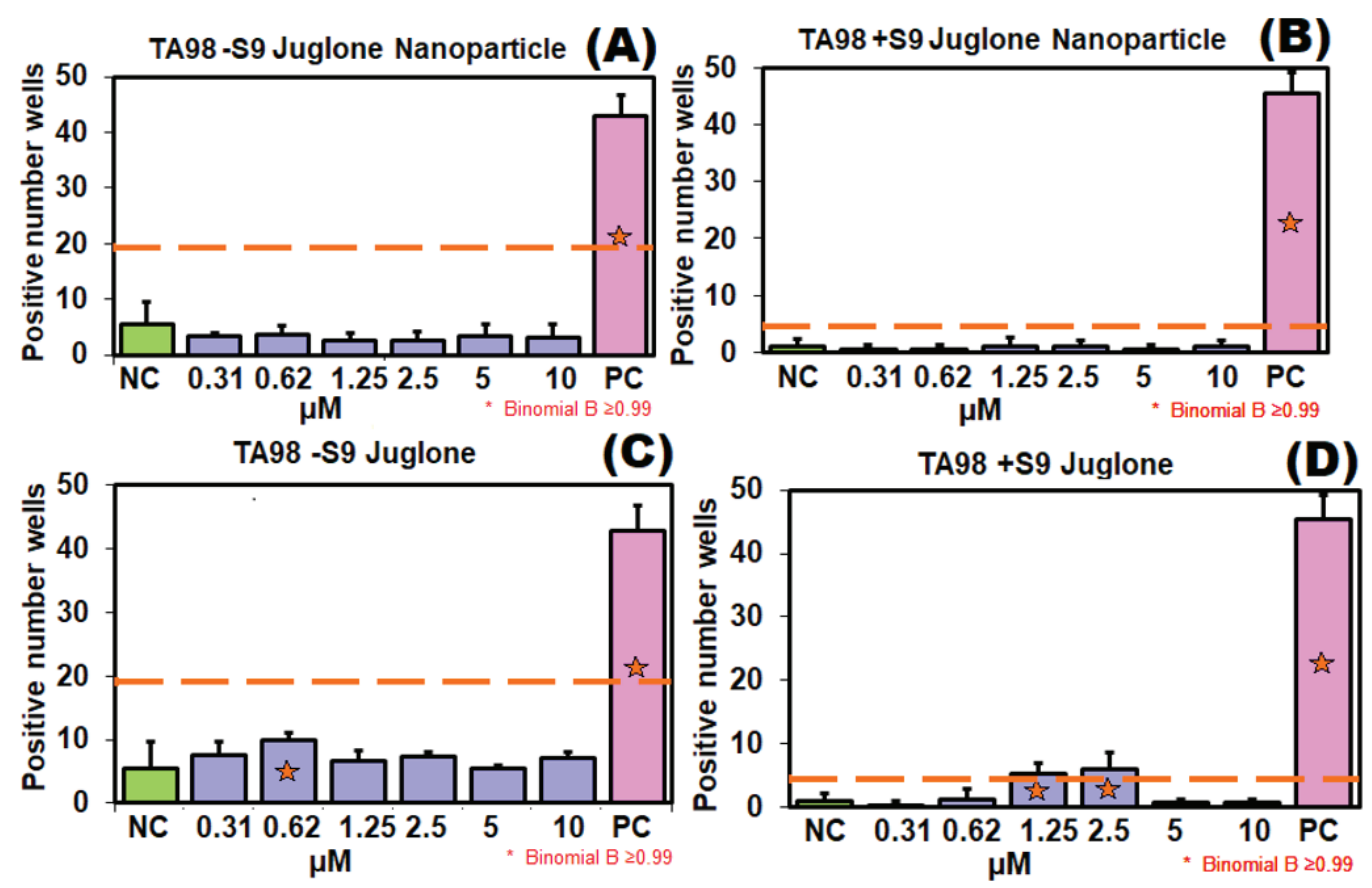

Figure 5 Potential mutagenicity in S. typhimurium TA98 treated with $0.31-10 \mu \mathrm{mol} / \mathrm{L}$ juglone: (A) TA98-S9 treated with JNPs; (B) TA98+S9 treated with JNPs; (C) TA98-S9 treated with free juglone; (D) TA98+S9 treated with free juglone; PC - positive control: 2-NF $(2 \mu \mathrm{g} / \mathrm{mL})$ and 4-NQO $(0.1 \mu \mathrm{g} / \mathrm{mL})$ without S9 and 2-AA $(1 \mu \mathrm{g} / \mathrm{mL})$ with S9; $\mathrm{NC}$ - negative control: water; ${ }^{*} \mathrm{~B}$ value $\geq 0.99$ 

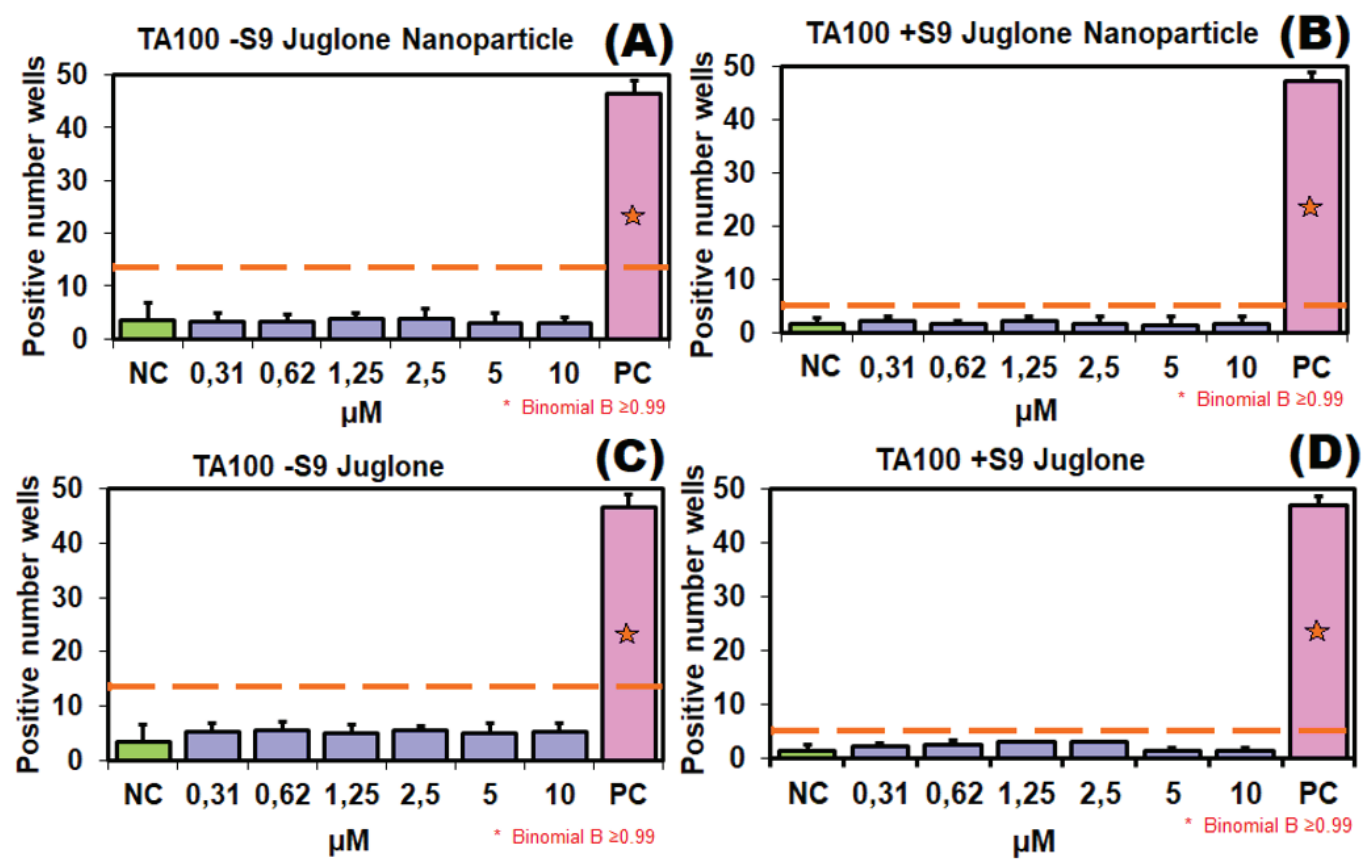

Figure 6 Potential mutagenicity in S. typhimurium TA100 treated with $0.31-10 \mu \mathrm{mol} / \mathrm{L}$ juglone: (A) TA100-S9 treated with JNPs; (B) TA100+S9 treated with JNPs; (C) TA100-S9 treated with free juglone; (D) TA100+S9 treated with free juglone; PC - positive control: 2-NF $(2 \mu \mathrm{g} / \mathrm{mL})$ and 4-NQO $(0.1 \mu \mathrm{g} / \mathrm{mL})$ without S9 and 2-AA $(2.5 \mu \mathrm{g} / \mathrm{mL})$ with S9; $\mathrm{NC}$ - negative control: water; *B value $\geq 0.99$

metabolic pathways that are somehow linked to energy metabolism. Saling et al. (17) observed that at low concentrations juglone stimulated oxygen consumption, lowered ATP content, increased the $\mathrm{NADH} / \mathrm{NAD}^{+}$ratio, and inhibited gluconeogenesis, whereas at high concentrations it triggered ATP production, hyperthermia, and even death. In the light of these findings, when S9 is added to a juglone-containing environment, products resulting from biotransformation by liver enzymes cause frameshift mutations in the TA98 strain. S9 is a liver extract containing active liver enzymes (P450 activity) which simulate hepatic metabolism in in vitro experiments (e.g., rat, hamster, or human) (17). In contrast, JNPs did not show mutagenic activity (Figure 5 and 6), probably because of the sustained and lower release of juglone as PLGA nanoparticles degrade. This elimination of mutagenic activity is important in terms of genotoxicity, as there is little information about the mutagenicity of pharmaceutical products using PLGA as carrier. Kruci et al. (50), for instance, found no mutagenic activity of PLGA/PHB fibrous nanocomposite implants. Similarly, anticancer drugs encapsulated in PLGA had toxicity compared to their freeform counterparts (51). This suggests that JNPs reduce genotoxicity and cytotoxicity through similar mechanisms.

\section{CONCLUSION}

Our findings have confirmed both the mutagenic and cytotoxic effects of free juglone, reported in literature. Compared to free juglone, the toxicity of PLGA nanoparticlecoated juglone was reduced at low doses due to controlled release properties. Furthermore, the nanoparticle system showed no mutagenicity and improved the biocompatibility of juglone, retaining at the same time the beneficial action of natural juglone.

Our findings provide important information about possible applications of the investigated JNPs. Their $\mathrm{IC}_{50}$ values were significantly higher than the toxic dose for the mutant Salmonella bacteria, which suggests that nanoparticle-coated juglone can kill prokaryotic cells without damaging eukaryotic cells. In other words, this system can be used in pharmaceutical fungicidal and bactericidal applications, which remains to be verified by future in vitro human cell line studies and in vivo animal experiments. Our findings also suggest that nanoparticlecoated juglone could be used in food safety applications and agriculture.

Funding

This research has not been supported by any organisation.

\section{Conflict of interest}

None to declare.

\section{REFERENCES}

1. Aithal BK, Kumar MR, Rao BN, Udupa N, Rao BS. Juglone, a naphthoquinone from walnut, exerts cytotoxic and genotoxic effects against cultured melanoma tumor cells. Cell Biol Int 2009;33:1039-49. doi: 10.1016/j. cellbi.2009.06.018

2. Coder KD. Black Walnut Allelopathy: Tree Chemical Warfare. Allelopathy Series. 2011;WSFNR11-10:1-13. 
3. Lee K-C. Nature and occurrence of juglone in Juglans nigra L [master of science]. Manhattan, Kansas: Kansas State University, Department of Horticulture; 1967.

4. Kocacaliskan I, Terzi I. Allelopathic effects of walnut leaf extracts and juglone on seed germination and seedling growth. J Hortic Sci Biotechnol 2001;76:436-40. doi: 10.1080/14620316.2001.11511390

5. Paulsen MT, Ljungman M. The natural toxin juglone causes degradation of $\mathrm{p} 53$ and induces rapid $\mathrm{H} 2 \mathrm{AX}$ phosphorylation and cell death in human fibroblasts. Toxicol Appl Pharmaco 2005;209:1-9. doi: 10.1016/j.taap.2005.03.005

6. Hejl AM, Koster KL. Juglone disrupts root plasma membrane $\mathrm{H}^{+}$-ATPase activity and impairs water uptake, root respiration, and growth in soybean (Glycine max) and corn (Zea mays). J Chem Ecol 2004;30:453-71. doi : 10.1023/b:joec.0000017988.20530.d5

7. Inbaraj JJ, Chignell CF. Cytotoxic action of juglone and plumbagin: a mechanistic study using $\mathrm{HaCaT}$ keratinocytes. Chem Res Toxicol 2004;17:55-62. doi: 10.1021/tx034132s

8. Esterbauer H, Cheeseman KH. Determination of aldehydic lipid peroxidation products: Malonaldehyde and 4-hydroxynonenal. Methods Enzymol 1990;186:407-21. doi: 10.1016/0076-6879(90)86134-h

9. Dama L, Poul B, Jadhav B. Antimicrobial activity of naphthoquinonic compounds. J Ecotoxicol Environ Monit 1998;8:213-5.

10. Arasoğlu T, Derman S, Mansuroğlu B, Uzunoğlu D, Koçyiğit BS, Gümüș B, Acar T, Tuncer B. Preparation, characterization, and enhanced antimicrobial activity: quercetin-loaded PLGA nanoparticles against foodborne pathogens. Turk J Biol 2017;41:127-40. doi: 10.3906/biy-1604-80

11. Tan DTC, Osman H, Mohamad S, Kamaruddin AH. Synthesis and antibacterial activity of juglone derivatives. J Chem Chem Engin 2012;6:84-9.

12. Xu H, Yu X, Qu S, Sui D. Juglone, isolated from Juglans mandshurica Maxim, induces apoptosis via down-regulation of AR expression in human prostate cancer LNCaP cells. Bioorg Med Chem Lett 2013;23:3631-4. doi: 10.1016/j. bmcl.2013.04.007

13. Zakavi F, Golpasand Hagh L, Daraeighadikolaei A, Farajzadeh Sheikh A, Daraeighadikolaei A, Leilavi Shooshtari Z. Antibacterial effect of Juglans regia bark against oral pathologic bacteria. Int J Dent 2013;2013:854765. doi: $10.1155 / 2013 / 854765$

14. Montenegro RC, Araújo AJ, Molina MT, Marinho Filho JDB, Rocha DD, Lopéz-Montero E, Goulart MO, Bento E, Alves APNN, Pessoa C, de Moraes MO, Costa-Lotufo LV. Cytotoxic activity of naphthoquinones with special emphasis on juglone and its 5-O-methyl derivative. Chem Biol Interact 2010;184:439-48. doi: 10.1016/j.cbi.2010.01.041

15. Shahidi Bonjar G, Aghighi S, Karimi Nik A. Antibacterial and antifungal survey in plants used in indigenous herbalmedicine of south east regions of Iran. J Biol Sci 2004;4:40512. doi: $10.3923 / j$ bs.2004.405.412

16. Arasoglu T, Mansuroglu B, Derman S, Gumus B, Kocyigit B, Acar T, Kocacaliskan I. Enhancement of antifungal activity of juglone (5-Hydroxy-1,4-naphthoquinone) using a Poly(D,L-lactic-co-glycolic acid) (PLGA) nanoparticle system. J Agric Food Chem 2016;64:7087-94. doi: 10.1021/ acs.jafc.6b03309

17. Saling SC, Comar JF, Mito MS, Peralta RM, Bracht A. Actions of juglone on energy metabolism in the rat liver
Toxicol Appl Pharmacol 2011;257:319-27. doi: 10.1016/j. taap.2011.09.004

18. Aithal KB, Kumar SM, Rao NB, Udupa N, Rao SB. Juglone, a naphthoquinone from walnut, exerts cytotoxic and genotoxic effects against cultured melanoma tumor cells. Cell Biol Int 2009;33:1039-49. doi: 10.1016/j. cellbi.2009.06.018

19. Strugstad M, Despotovski S. A summary of extraction, synthesis, properties, and potential uses of juglone: A literature review. J Ecosyst Management 2013;13(3):1-16.

20. Aithal KB, Kumar S, Rao BN, Udupa N, Rao SBS. Tumor growth inhibitory effect of juglone and its radiation sensitizing potential: in vivo and in vitro studies. Integr Cancer Ther 2012;11:68-80. doi: 10.1177/1534735411403477

21. Abdollahi S, Lotfipour F. PLGA- and PLA-based polymeric nanoparticles for antimicrobial drug delivery. Biomed Int 2012;3:1-11.

22. Dinarvand R, Sepehri N, Manoochehri S, Rouhani H, Atyabi F. Polylactide-co-glycolide nanoparticles for controlled delivery of anticancer agents. Int J Nanomedicine 2011;6:87795. doi: 10.2147/IJN.S18905

23. Esmaeili F, Hosseini-Nasr M, Rad-Malekshahi M, Samadi N, Atyabi F, Dinarvand R. Preparation and antibacterial activity evaluation of rifampicin-loaded poly lactide-coglycolide nanoparticles. Nanomedicine 2007;3:161-7. doi: 10.1016/j.nano.2007.03.003

24. Cheow WS, Chang MW, Hadinoto K. Antibacterial efficacy of inhalable levofloxacin-loaded polymeric nanoparticles against $E$. coli biofilm cells: the effect of antibiotic release profile. Pharmaceut Res 2010;27:1597-609. doi: 10.1007/ s11095-010-0142-6

25. Kerimoglu O, Alarcin E. Poly(lactic-co-glycolic acid) based drug delivery devices for tissue engineering and regenerative medicine. ANKEM Derg 2012;26:86-98. doi: 10.5222/ ankem.2012.086

26. Arasoglu T, Derman S, Mansuroglu B, Yelkenci G, Kocyigit B, Gumus B, Acar T, Kocacaliskan I. Synthesis, characterization and antibacterial activity of juglone encapsulated PLGA nanoparticles. J Appl Microbiol 2017;123:1407-19. doi: 10.1111/jam.13601

27. Derman S. Caffeic acid phenethyl ester loaded PLGA nanoparticles: effect of various process parameters on reaction yield, encapsulation efficiency, and particle size. J Nanomater 2015;2015:ID341848. doi: 10.1155/2015/341848

28. Arasoglu T, Derman S, Mansuroglu B. Comparative evaluation of antibacterial activity of caffeic acid phenethyl ester and PLGA nanoparticle formulation by different methods. Nanotechnology 2015;27(2):025103. doi: 10.1088/0957-4484/27/2/025103

29. Mosmann T. Rapid colorimetric assay for cellular growth and survival: application to proliferation and cytotoxicity assays. J Immunol Methods 1983;65:55-63. doi: 10.1016/0022-1759(83)90303-4

30. Wallin RF, Arscott E. A practical guide to ISO 10993-5: Cytotoxicity, 1998 [displayed on 29 November 2019]. Available at https://www.namsa.com/wp-content/ uploads/2015/10/A-Practical-Guide-to-ISO-10993-5 Cytotoxicity.pdf

31. Abe K, Matsuki N. Measurement of cellular 3-(4,5-dimethylthiazol-2-yl)-2, 5-diphenyltetrazolium bromide (MTT) reduction activity and lactate dehydrogenase 
release using MTT. Neurosci Res 2000;38:325-9. doi: 10.1016/s0168-0102(00)00188-7

32. Xenometrix. Ames MPFTM 98/100 Microplate Format Mutagenicity Assay. Stilwell (CA): Xenometrix; 2015.

33. Hamel A, Roy M, Proudlock R. The bacterial reverse mutation test. In; Proudlock R, editor. Genetic toxicology testing. London: Academic Press Inc.; 2016. p. 79-138.

34. Flückiger-Isler S, Kamber M. Direct comparison of the Ames microplate format (MPF) test in liquid medium with the standard Ames pre-incubation assay on agar plates by use of equivocal to weakly positive test compounds. Mutat Res 2012;747:36-45. doi: 10.1016/j.mrgentox.2012.03.014

35. Arasoglu T, Derman S. Assessment of the antigenotoxic activity of Poly(D,L-lactic-co-glycolic acid) nanoparticles loaded with caffeic acid phenethyl ester using the ames Salmonella/microsome assay. J Agric Food Chem 2018;66:6196-204. doi: 10.1021/acs.jafc.8b01622

36. Escobar P, Kemper R, Tarca J, Nicolette J, Kenyon M, Glowienke S, Sawant S, Christensen J, Johnson T, McKnight C, Ward G, Galloway SM, Custer L, Gocke E, O’Donovan MR, Braun K, Snyder RD, Mahadevan B. Bacterial mutagenicity screening in the pharmaceutical industry. Mutation Res 2013;752:99-118. doi: 10.1016/j. mrrev.2012.12.002

37. Dutta D, Paul B, Mukherjee B, Mondal L, Sen S, Chowdhury C, Debnath MC. Nanoencapsulated betulinic acid analogue distinctively improves colorectal carcinoma in vitro and in vivo. Sci Rep 2019;9(1):11506. doi: 10.1038/s41598-01947743-y

38. Ersoz M, Erdemir A, Duranoglu D, Uzunoglu D, Arasoglu T, Derman S, Mansuroglu B. Comparative evaluation of hesperetin loaded nanoparticles for anticancer activity against C6 glioma cancer cells. Artif Cells Nanomed Biotechnol 2019;47:319-29. doi: 10.1080/21691401.2018.1556213

39. Bhattacharya S, Mondal L, Mukherjee B, Dutta L, Ehsan I, Debnath MC, Gaonkar RH, Pal MM, Majumdar S. Apigenin loaded nanoparticle delayed development of hepatocellular carcinoma in rats. Nanomedicine 2018;14:1905-17. doi: 10.1016/j.nano.2018.05.011

40. Ramirez O, Motta-Mena LB, Cordova A, Garza KM. A small library of synthetic di-substituted 1,4-naphthoquinones induces ROS-mediated cell death in murine fibroblasts. PloS One 2014;9(9):e106828. doi: 10.1371/journal.pone.0106828

41. Kumari A, Yadav SK, Yadav SC. Biodegradable polymeric nanoparticles based drug delivery systems. Colloids and Surf
B Biointerfaces 2010;75:1-18. doi: 10.1016/j. colsurfb.2009.09.001

42. Terzi I. Allelopathic effects of juglone and walnut leaf and fruit hull extracts on seed germination and seedling growth in muskmelon and cucumber. Asian J Chem 2009;21:1840-6.

43. Kocaçalişkan I, Ceylan M, Terzi I. Effects of juglone on seedling growth in intact and coatless seeds of cucumber (Cucumis sativus cv. Beith Alpha). Sci Res Essays 2009;4:039-41.

44. Topal S, Kocaçalişkan I, Arslan O, Tel AZ. Herbicidal effects of juglone as an allelochemical. Phyton 2007;46:259-69.

45. Terzi I, Kocaçalişkan I, Benlioğlu O, Solak K. Effects of juglone on growth of cucumber seedlings with respect to physiological and anatomical parameters. Acta Physiol Plant 2003;25:353-6. doi: 10.1007/s11738-003-0016-1

46. Babula P, Adam V, Havel L, Kizek R. Noteworthy secondary metabolites naphthoquinones-their occurrence, pharmacological properties and analysis. Curr Pharmaceut Anal 2009;5:47-68. doi: 10.2174/157341209787314936

47. Babula P, Vaverkova V, Poborilova Z, Ballova L, Masarik M, Provaznik I. Phytotoxic action of naphthoquinone juglone demonstrated on lettuce seedling roots. Plant Physiol Biochem 2014;84:78-86. doi: 10.1016/j.plaphy.2014.08. 02748

48. Tikkanen L, Matsushima T, Natori S, Yoshihira K. Mutagenicity of natural naphthoquinones and benzoquinones in the Salmonella/microsome test. Mutat Res 1983;124:2534. doi: 10.1016/0165-1218(83)90182-9

49. Gaivão I, Sierra LM, Comendador MA. The $w / w^{+}$SMART assay of Drosophila melanogaster detects the genotoxic effects of reactive oxygen species inducing compounds. Mutat Res 1999;440:139-45. doi: 10.1016/s13835718(99)00020-0

50. Krucińska I, Żywicka B, Komisarczyk A, Szymonowicz M, Kowalska S, Zaczyńska E, Struszczyk M, Czarny A, Jadczyk P, Umińska-Wasiluk B. Biological properties of low-toxicity PLGA and PLGA/PHB fibrous nanocomposite implants for osseous tissue regeneration. Part I: Evaluation of potential biotoxicity. Molecules 2017;22:pii:E2092. doi: 10.3390/ molecules22122092

51. Yoo HS, Lee KH, Oh JE, Park TG. In vitro and in vivo antitumor activities of nanoparticles based on doxorubicin-PLGA conjugates. J Control Release 2000;68:419-31. doi: 10.1016/ s0168-3659(00)00280-7

\section{Citotoksični i mutageni potencijal juglona u slobodnom i nanoinkapsuliranom obliku}

Usprkos dokazanim herbicidnim, protubakterijskim, protuvirusnim, protugljivičnim i antioksidacijskim učincima, primjena juglona (5-hidroksi-1,4-naftokinon) ograničena je zbog njegove slabe topljivosti u vodi te alelopatskoga i toksičnoga djelovanja. Cilj je novijih istraživanja bio ukloniti te prepreke povećanjem njegove topljivosti i boljom regulacijom njegova otpuštanja $\mathrm{s}$ pomoću sustava nanočestica. Ovo je, međutim, prvo istraživanje u kojem je sintetiziran i karakteriziran juglon u omotaču polimernih nanočestica te uspoređen sa slobodnim juglonom u smislu citotoksičnosti u mišjih fibroblasta (L929) i biljnih alfalfa stanica te mutagenosti u bakterije Salmonella typhimurium TA98 i TA100. Mišje i biljne stanice izložene slobodno u nanoinkapsuliranome juglonu iskazale su smanjenu vijabilnost, koja je ovisila o dozi i vremenu izloženosti, ali je to djelovanje bilo značajno slabije s juglonom u nanočesticama pri nižim dozama. Za razliku od slobodnoga juglona, nanočestice s juglonom nisu djelovale mutageno na S. typhimurium soj TA98 s metaboličkim aktivacijskim enzimom S9. Budući da svi rezultati pokazuju kako je inkapsuliranje juglona u polimerne nanočestice smanjilo njegov toksični $\mathrm{i}$ mutageni učinak, ovaj oblik ima obećavajući potencijal za primjenu u medicini, poljoprivredi i u području sigurnosti hrane. 